\title{
The Impact of Innovation on the Performance of Manufacturing Enterprises in Vietnam
}

\author{
Thi Anh Van Nguyen*, Khac Hieu Nguyen \\ Department of Industrial Management, HCMC University of Technology and Education, Ho Chi Minh City, 700000, Vietnam
}

\begin{tabular}{l} 
A R T I C L E I N F O \\
\hline Article history: \\
Received: 23 August, 2020 \\
Accepted: 29 September, 2020 \\
Online: 20 October, 2020 \\
\hline Keywords: \\
Product Innovation \\
Technology Innovation \\
Organization Innovation \\
Firm Performance \\
Manufacturing Enterprises \\
\hline
\end{tabular}

\section{Introduction}

Nowadays, with the changing business environment, innovation is the key to decide the success or failure of many businesses. In the world, innovation takes place quickly and strongly. Many studies show that innovation (technological innovation, product innovation, organizational innovation) has a positive effect on the performance of enterprises. However, most of the studies in Vietnam focusing on small and medium-sized enterprises and these studies mostly ignored the impact of the innovation factor on the performance of enterprises. Ho Chi Minh City is the largest economic center in Vietnam, and a place to welcome investment waves as well as technological innovations. In recent years, the city has had a policy of investing in the development of four key industries: the Food processing industry; Pharmaceutical-rubber industry; Mechanical industry and Electronics \& Information technology. However, measuring the impact of policies as well as the innovation on performance is an issue of little concern. This is a research gap for the authors to implement the study "The impact of innovation on the performance of manufacturing enterprises in Vietnam". This paper examines the relationship between innovation (including technological innovation, product innovation, organizational innovation) and business performance (including revenue and profits). From the results, the paper proposes some recommendations to improve the performance of enterprises in four key industries in Ho Chi Minh City.

In this article, innovation includes technological innovation, product innovation, and organizational innovation. Business

*Corresponding Author: Thi Anh Van Nguyen, Email: anhvan@hcmute.edu.vn www.astesj.com

https://dx.doi.org/10.25046/aj0505120 performance is analyzed and measured based on revenue and profit.

\section{Literature review and research model}

This section presents related concepts such as innovation, product innovation, technological innovation, organizational innovation, and the four key industries. Studies of the impact of innovation on the performance will be reviewed in the following part. Finally, a research model will be proposed based on the previous researches.

\subsection{Related concepts}

\subsubsection{Innovation:}

Innovation has become the main driving force of economic strength and national competitiveness. Most people think that innovation only brings technological aspects to create outstanding new products, such as Apple's iPad, Sony's PlayStation, or applying artificial intelligence to business, etc. Others argue that innovation is only associated with research and development (R\&D) activities conducted at national universities and laboratories. This concept is too limited because innovation has a much broader meaning [1].

Innovation nowadays is understood as "a new idea, creative thought, or new imagination in the form of equipment or methods". Innovation is often seen as the application of better solutions to meet new requirements and existing market needs. The innovation takes place through the provision of new products, new processes, new services, new technologies or new efficient business models 
[2]. Innovation is related invention, but not like it, because innovation is most likely related to the actual implementation of an invention (i.e. new/improved ability) to create a meaningful impact in the market or society, and not all innovations require an invention [3], [4].

A fairly complete definition of the Organization for Economic Co-operation and Development (OECD)'s innovation is "implementing a new product or a significant improvement (for a particular product or service), a new process, marketing method, or a new organizational method in business practices, workplace organization, or external relations " [5]. From here, we can see the concept of innovation including technology and non-technology. In this study, the concept of innovation used includes product/service innovation; technological innovation and organizational innovation.

\subsubsection{Product innovation}

Product innovation refers to the creation and introduction of new products and services, whereby the direction of innovation is associated with the speed of innovation (necessary time to develop new products), the ability to replace regular products with improved versions and the ability to launch new products to new markets [5] [6].

\subsubsection{Technology innovation}

Technology innovation is the replacement of a major part or the whole of an existing technology with more advanced and more efficient technology. Technology innovation aims to increase the productivity, quality and efficiency of the production process or create a new product or service to serve the market.

Technological innovation includes new products and processes and significant technological changes of products and processes [7]. An innovation has been made if it is launched in the market. Technological innovation is inevitable for companies that want to develop and remain competitive or achieve the goal of entering new markets [8]. There are many variables that represent technological innovation such as: technology infrastructure (computers, internet, R\&D costs, etc.); government support for technology; enterprise competencies (enterprise training, technology strategic plan, ...) and corporate culture (human resource level, management support, ...).

\subsubsection{Organization innovation}

Organization innovation involves upgrading management processes through new business approaches. Organization innovation can improve business performance by supporting necessary changes, reducing transaction and administrative costs, improving workplace satisfaction, reducing input costs [9]. Organization innovation includes training programs, product design programs, and management group creativity in problemsolving [10]. In 2006, authors proposed that organizational innovation involves management efforts to refresh organizational habits, procedures, mechanisms or systems to create ultimate ecological innovation.

\subsubsection{Four key industries}

According to the Ho Chi Minh City General Statistics Office [11], the codes for the four key industries are shown in Table 1 as follows:
Table 1: Industries belong to 4 key industries groups

\begin{tabular}{|c|c|c|}
\hline $\begin{array}{l}\text { Key } \\
\text { industries } \\
\text { group }\end{array}$ & $\begin{array}{l}\text { Industry } \\
\text { code }\end{array}$ & Industry name \\
\hline Foods (1) & 11 & Beverage manufacturing \\
\hline \multirow{3}{*}{$\begin{array}{l}\text { Pharmaceutical } \\
\text { chemicals - } \\
\text { Rubber (2) }\end{array}$} & 20 & $\begin{array}{l}\text { Chemicals and chemical products } \\
\text { manufacturing }\end{array}$ \\
\hline & 21 & $\begin{array}{l}\text { Medicine, pharmaceutical chemicals and } \\
\text { pharmacognosy manufacturing }\end{array}$ \\
\hline & 22 & $\begin{array}{l}\text { Rubber and plastic products } \\
\text { manufacturing }\end{array}$ \\
\hline \multirow[t]{6}{*}{ Mechanical (3) } & 24 & Metal production \\
\hline & 25 & $\begin{array}{l}\text { Manufacturing products from } \\
\text { prefabricated metal (except machinery } \\
\text { and equipment) }\end{array}$ \\
\hline & 28 & $\begin{array}{l}\text { Producing machines and equipment not } \\
\text { classified in any category }\end{array}$ \\
\hline & 29 & Motor vehicles manufacturing \\
\hline & 30 & $\begin{array}{l}\text { Other means of transportation } \\
\text { manufacturing }\end{array}$ \\
\hline & 27 & Electrical equipment manufacturing \\
\hline $\begin{array}{l}\text { Electronics } \\
\text { and } \\
\text { information } \\
\text { technology (4) }\end{array}$ & 26 & $\begin{array}{l}\text { Manufacturing electronic products, } \\
\text { computers and optical products }\end{array}$ \\
\hline
\end{tabular}

\subsection{Study overview}

\subsubsection{Overview of related research works in the world}

Currently, the issue of innovation is being strongly concerned in the world, especially with the strong development of the industrial revolution 4.0. Therefore, there are a lot of researches related to this field. In the context of the topic, the author reviews a number of studies related to the question of how innovation affects the company's operating results such as revenue, profits, and costs.

In 2008, the researcher collected data from 7302 companies in Europe to test the relationship of using technology via the internet, different types of innovation and the performance of enterprises. Research results indicated that all types of product and process innovation (including products related to e-commerce and traditional products) have positive effects on revenue and labor force growth [12]. Another research studied small and medium-sized companies in Portugal on the relationship between Total Quality Management (TQM), customer orientation, innovation and the operation of businesses [13]. The author concluded that most of the components of TQM affect customer orientation and business performance. Meanwhile TQM does not affect innovation. However, innovation affects business performance [13].

In 2010, the research on 600 small and medium-sized companies in Australia was done and proposed that the enterprise formal structure and innovation strategy are the main keys affecting enterprises' operations [14].

In 2014, the relationship between innovation (process innovation, product innovation, organizational innovation) to the performance of enterprises in 121 enterprises in Taiwan were investigated in some other papers. They suggested that 
organizational innovation has the most positive impact on the performance of businesses. Meanwhile, process innovation and product innovation affect organizational innovation, and organizational innovation affects the performance of businesses [15].

In 2017, Rangus and Slavec examined the relationship between organizational characteristics, firm's innovation and firm performance. After studying 421 manufacturing and service companies in Slovenian, they proposed that innovation has a positive impact on the performance of businesses [16].

Recently, a study used the Ordinary Least Squares (OLS) and simultaneous equation models to analyze large data which included 63303 firms from 13 different European Union countries. The results showed that both human capital and the number of adopted eco-innovation strategies influenced positively firm performance [17]. Another study analyzed the impact of innovation on firm performance in developing economies. The study used data from 8,551 enterprises which were surveyed between 2014 and 2016 covering 19 Sub Saharan African countries. The CDM model and ordinary least squares method were adopted to analyze the effect of domestic R\&D on innovation output, and the contribution of innovation to firm performance in the sub region. The result showed that both product and process innovations had a positive and significant effect on firm performance [18].

In general, although studies are conducted at different times in many countries, the results are quite similar in testing the relationship between innovation and business performance.

In the industrial revolution 4.0 and the current globalization, innovation is really an urgent issue for businesses in Vietnam in general and Ho Chi Minh City in particular. However, according to experts, the rate of innovation in Vietnamese enterprises is very low. There are nearly 600,000 businesses in the country, most of them are using technology lagging behind the average level of the world from two to three generations.

Ho Chi Minh City is an important economic, cultural and educational center of Vietnam. The industrial production value of Ho Chi Minh City accounts for about $45 \%$ of industrial output value in the southern key economic region and contributes about $26 \%$ of the national industrial production scale [19]. The investment policy of Ho Chi Minh City is to focus on investing in four key industries: mechanical engineering, electronics, chemicals - rubber - plastic and food processing. However, studies on innovation issues in these enterprises and the impact of innovation on business performance are limited.

Most of the research on innovation and business performance in Vietnam is about small and medium enterprises (SMEs). In 2008, some researchers examined the relationship between innovation and export at Vietnamese SMEs and concluded that innovation has an impact on export [20]. For instance, some authors surveyed 389 SMEs in Can Tho City in 2011. The results showed that factors such as the level of access to government support policies, the education level of the business owner, the size of the business, the social relationship of the enterprise and the revenue growth rate affect the efficiency of business operation of SMEs in the Can Tho city [21].
One of the few studies on innovation to business results of Vietnamese enterprises was conducted by Quan Minh Nhut in 2018 [22]. The author surveyed primary information from 55 randomly selected agricultural enterprises representing the agricultural enterprises in Ben Tre province. After studying the effect of the scientific and technological investment on enterprises' business results, discriminatory analysis results showed that there are 4 statistically significant factors affecting the difference of enterprises' profit: total revenue, investment capital for application of science and technology, type of enterprises and market expansion [22].

Finally, in 2019, some authors did research on the drivers of firm productivity, focusing on the role of international management standards certification in Vietnam. They concluded that the possession of an internationally recognized standard certificate leads to significant productivity. They also proposed that the effect of certification on productivity is particularly strong for firms with technological innovation [23].

\subsection{Research model}

From the above results, most of the researches concluded that innovation has a positive impact on the performance of enterprises. Therefore, the author proposes a research model with the dependent variable as the business performance of the enterprise, measured by revenue and profit. Independent variables are product innovation, technological innovation and organizational innovation.

After reviewing the above studies, the author proposes the following model:

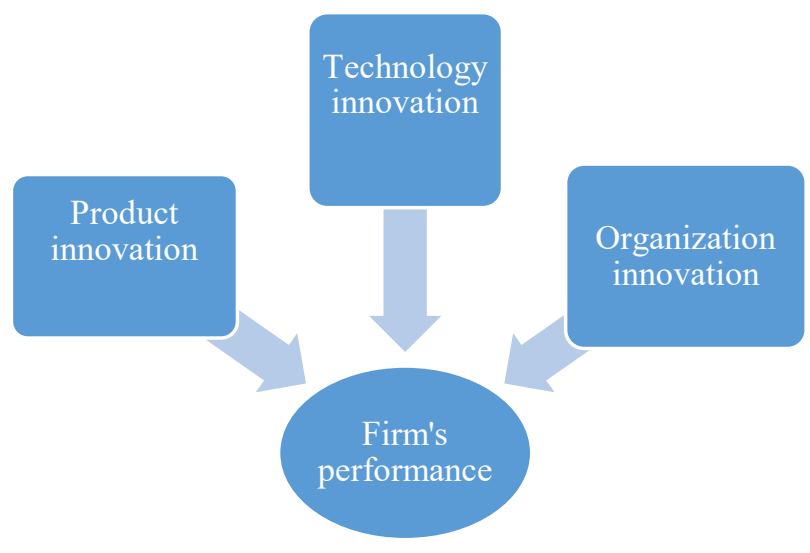

Figure 1: Proposed Research model

\section{Research methodology and data}

In order to test the proposed research model (Figure 1), the author uses Ordinary Least Squares (OLS) regression. There are many studies which did research about firm performance by OLS method and the results are consistent and reliable [17], [18], [24][26]. In this study, the authors suggest dependent variable denoted by $\mathrm{Yi}$, independent variable denoted by $\mathrm{Xi}$ and error denoted as $\mathrm{u}_{\mathrm{i}}$, a constant $\beta 1$ and a vector of regression coefficients $\beta 2$. The regression equation is expressed as follows: 
In which, $\mathrm{Yi}$ is a vector of dependent variables including: Revenue, Profit, $\mathrm{Xi}$ is an independent variable vector. Details of variable encoding and definitions are shown in the following table.

$$
Y_{i}=\beta_{1}+\beta_{2} X_{i}+u_{i}
$$

Table 2: Variables names and definitions

\begin{tabular}{|c|c|}
\hline Variable name & Definition \\
\hline Revenue & $\begin{array}{l}\text { Log10 revenue of the enterprise in } 2018 \text { (Unit: } \\
\text { Million VND) }\end{array}$ \\
\hline Profit & $\begin{array}{l}\text { Log } 10 \text { profit of the enterprise in } 2018 \text { (Unit: Million } \\
\text { VND) }\end{array}$ \\
\hline \multicolumn{2}{|c|}{ Product Innovation } \\
\hline $\begin{array}{l}\text { New } \\
\text { products/services }\end{array}$ & $\begin{array}{l}\text { Binary variable, equal to } 1 \text { if the enterprise develops } \\
\text { new products/services or innovates the existing } \\
\text { products/services. }\end{array}$ \\
\hline $\begin{array}{l}\text { Quantity of new } \\
\text { product types }\end{array}$ & $\begin{array}{l}\text { Quantity of new products/services launched to the } \\
\text { market in } 2018\end{array}$ \\
\hline $\begin{array}{l}\text { Cost for testing } \\
\text { new } \\
\text { products/services }\end{array}$ & $\begin{array}{l}\text { Cost for testing new products/services in 2018. (Unit: } \\
\text { Million VND) }\end{array}$ \\
\hline \multicolumn{2}{|c|}{ Technology Innovation } \\
\hline $\begin{array}{l}\text { New technology } \\
\text { investment }\end{array}$ & $\begin{array}{l}\text { Binary variable, equal to } 1 \text { if there is any technology } \\
\text { innovation or improvement of the current technology. }\end{array}$ \\
\hline $\begin{array}{l}\text { Cost of hiring } \\
\text { machines and } \\
\text { technology }\end{array}$ & $\begin{array}{l}\text { Expenses for hiring/buying specialized machines, } \\
\text { equipment, software and new technologies in } 2018 . \\
\text { (Unit: Million VND) }\end{array}$ \\
\hline $\begin{array}{l}\text { Cost of } \\
\text { improving } \\
\text { machines and } \\
\text { technology }\end{array}$ & $\begin{array}{l}\text { Expenses for the improvement of machines, } \\
\text { equipment, specialized software and technologies in } \\
\text { 2018. (Unit: Million VND) }\end{array}$ \\
\hline $\begin{array}{l}\text { Cost of } \\
\text { technology } \\
\text { project research }\end{array}$ & $\begin{array}{l}\text { Expenses for technology project research in } 2018 . \\
\text { (Unit: Million VND) }\end{array}$ \\
\hline $\begin{array}{l}\text { Level of } \\
\text { computer } \\
\text { equipment }\end{array}$ & $\begin{array}{l}\text { Level of computer equipment is calculated by the } \\
\text { quantity of current equipment dividing by the actual } \\
\text { quantity of the equipment needed for work. }\end{array}$ \\
\hline $\begin{array}{l}\text { Using } \\
\text { internet/computer } \\
\text { network }\end{array}$ & $\begin{array}{l}\text { Binary variable, equal to } 1 \text { if the enterprise use } \\
\text { internet or computer network }\end{array}$ \\
\hline $\begin{array}{l}\text { Private } \\
\text { information } \\
\text { website }\end{array}$ & $\begin{array}{l}\text { Binary variable, equal to } 1 \text { if the enterprise has its } \\
\text { own portal/website. }\end{array}$ \\
\hline $\begin{array}{l}\text { Cloud computing } \\
\text { model }\end{array}$ & $\begin{array}{l}\text { Binary variable, equal to } 1 \text { if the enterprise uses cloud } \\
\text { computing model for work. }\end{array}$ \\
\hline \multicolumn{2}{|c|}{ Organization Innovation } \\
\hline $\begin{array}{l}\text { New marketing } \\
\text { method }\end{array}$ & $\begin{array}{l}\text { Binary variable, equal to } 1 \text { if the enterprise has a new } \\
\text { marketing method, new experience for customers. }\end{array}$ \\
\hline $\begin{array}{l}\text { New } \\
\text { management } \\
\text { method }\end{array}$ & $\begin{array}{l}\text { Binary variable, equal to } 1 \text { if the enterprise has } \\
\text { implemented a new management and organization } \\
\text { method. }\end{array}$ \\
\hline $\begin{array}{l}\text { Research \& } \\
\text { Development } \\
\text { (R\&D) }\end{array}$ & $\begin{array}{l}\text { Binary variable, equal to } 1 \text { if the enterprise has R\&D } \\
\text { department. }\end{array}$ \\
\hline $\begin{array}{l}\text { Science and } \\
\text { Technology } \\
\text { Development } \\
\text { Fund }\end{array}$ & $\begin{array}{l}\text { Binary variable, equal to } 1 \text { if the enterprise has } \\
\text { established Science and Technology Development } \\
\text { Fund. }\end{array}$ \\
\hline Training cost & $\begin{array}{l}\text { Labor/human resource training costs in technology } \\
\text { hiring/innovation/research activities in } 2018 \text { (Unit: } \\
\text { Million VND). }\end{array}$ \\
\hline $\begin{array}{l}\text { Government's } \\
\text { support }\end{array}$ & $\begin{array}{l}\text { Binary variable, equal to } 1 \text { if the government assists } \\
\text { in innovation. }\end{array}$ \\
\hline
\end{tabular}

The data was from the surveys conducted in enterprises in four key industries including: Food processing industry; Pharmaceutical-rubber industry; Mechanical industry and Electronics \& Information technology. The results obtained 806 qualified answers.

\section{Research results and discussion}

\subsection{Descriptive statistics}

Survey results collected 806 qualified samples, of which enterprises in the field of mechanical manufacturing - automation accounted for 47.8\%; plastic - rubber sector (29.5\%); food processing (16\%); and the lowest is information technology electronics and telecommunications $(6.7 \%)$.

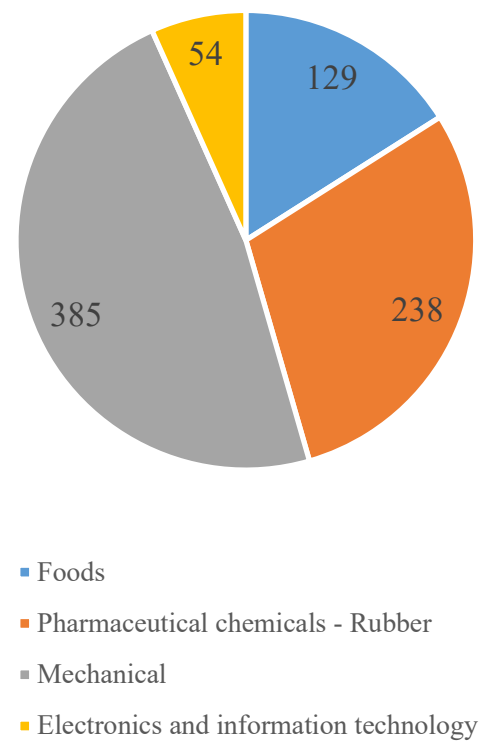

Figure 2: Number of surveyed companies in four sectors

\subsection{Regression results with the dependent variable REVENUE and PROFIT.}

To see the impact of innovation on the performance of enterprises, the authors analyze data by the OLS regression method. Details of regression analysis results are presented in Table 3 and Table 4. In order to ensure that the regression model is not faulty, the authors tested multi-collinearity and heteroscedasticity error of the model. The results of the multicollinearity test show that all the magnification coefficients are less than two, hence, we can conclude that the regression equation does not occur the multi-collinearity phenomenon. The heteroscedasticity error is checked by the White test. The results show that there is no heteroscedasticity error because of the significance of Prob $(\mathrm{F})>10 \%$.

Table 4: Regression results with the dependent variable is REVENUE

\begin{tabular}{|l|l|l|l|}
\hline Observed variables & Coef & P-Value & VIF \\
\hline Intercept & 3.866 & 0.000 & \\
\hline Cost of hiring machines and technology & $0.000001^{* *}$ & 0.028 & 1.10 \\
\hline $\begin{array}{l}\text { Expenses for improving machines and } \\
\text { technology }\end{array}$ & $0.000111^{* * *}$ & 0.000 & 1.07 \\
\hline Cost of technology project research & -0.000004 & 0.834 & 1.19 \\
\hline
\end{tabular}




\begin{tabular}{|l|l|l|l|}
\hline Cost for testing new service/products & $0.000027^{* * *}$ & 0.004 & 1.06 \\
\hline Training cost & $0.000324^{*}$ & 0.078 & 1.24 \\
\hline Quantity of new product types & 0.00408 & 0.254 & 1.15 \\
\hline Level of computer equipment & 0.000384 & 0.579 & 1.04 \\
\hline Using internet/computer network & $0.367^{* *}$ & 0.045 & 1.07 \\
\hline Private information website & $0.2581^{* * *}$ & 0.000 & 1.18 \\
\hline Cloud computing model & -0.0519 & 0.529 & 1.15 \\
\hline Government's support & $0.1935^{* *}$ & 0.005 & 1.12 \\
\hline R\&D & -0.0357 & 0.680 & 1.31 \\
\hline $\begin{array}{l}\text { Science and Technology Development } \\
\text { Fund }\end{array}$ & 0.212 & 0.239 & 1.16 \\
\hline New products/services & 0.0349 & 0.701 & 1.67 \\
\hline Investment in new technologies & $0.2904^{* * *}$ & 0.000 & 1.61 \\
\hline New marketing method & $-0.2525^{* * *}$ & 0.009 & 1.49 \\
\hline New management method & $0.5946^{* * *}$ & 0.000 & 1.23 \\
\hline R-squared & 0.302649 & \\
\hline F-statistic & $20.06607 * * *$ & \\
\hline Prob(F-statistic) & 0.000000 & \\
\hline Not $* * * a n$
\end{tabular}

Note: $*, * *$ and $* * *$ represent for the level of significance $10 \%, 5 \%$ and $1 \%$, respectively.

The results of the regression analysis show that the factors affecting revenue are Expenses for hiring machines and technology; Expenses for improving machines and technology; Cost for testing new service/products; Training costs; Using internet/computer network; Private information website; Government's support; Investment in new technologies; New marketing methods; New management method.

Table 5: Regression results with the dependent variable is PROFIT

\begin{tabular}{|l|l|l|l|}
\hline Variable & Coef & P-Value & VIF \\
\hline Intercept & 5.1103 & 0.000 & \\
\hline Cost of hiring machines and technology & $0.000001^{* * *}$ & 0.000 & 1.10 \\
\hline $\begin{array}{l}\text { Expenses for improving machines and } \\
\text { technology }\end{array}$ & $0.000023^{* * *}$ & 0.000 & 1.07 \\
\hline Cost of technology project research & -0.000004 & 0.126 & 1.19 \\
\hline Cost for testing new service/products & $0.000008^{* * *}$ & 0.000 & 1.06 \\
\hline Training cost & $0.000082^{* * *}$ & 0.004 & 1.24 \\
\hline Quantity of new product types & $0.001156^{* *}$ & 0.037 & 1.15 \\
\hline Level of computer equipment & $0.000172^{*}$ & 0.108 & 1.03 \\
\hline Using internet/computer network & 0.0101 & 0.722 & 1.07 \\
\hline Private information website & -0.00092 & 0.915 & 1.18 \\
\hline Cloud computing model & -0.0051 & 0.691 & 1.15 \\
\hline Government's support & 0.0027 & 0.800 & 1.12 \\
\hline R\&D & $0.0305^{* *}$ & 0.023 & 1.31 \\
\hline $\begin{array}{l}\text { Science and Technology Development } \\
\text { Fund }\end{array}$ & $0.1019^{* * *}$ & 0.000 & 1.16 \\
\hline New products/services & 0.0143 & 0.309 & 1.67 \\
\hline Investment in new technologies & -0.0018 & 0.879 & 1.61 \\
\hline New marketing method & 0.0006 & 0.967 & 1.49 \\
\hline New management method & $0.02431^{* * *}$ & 0.007 & 1.23 \\
\hline R-squared & 0.261308 & \\
\hline F-statistic & $16.37629^{* * *}$ & \\
\hline Prob(F-statistic) & 0.000000 & \\
\hline
\end{tabular}

Note: $*, * *$ and $* * *$ represent for the level of significance $10 \%, 5 \%$ and $1 \%$, respectively.

The results of the regression analysis show that the factors affecting profit are: Expenses for hiring machines and technology; Expenses for improving machines and technology; Cost for testing new services/products; Training costs; Quantity of new product types; Level of computer equipment; R\&D; Science and Technology Development Fund; New management method.

\subsection{Research results discussion}

Factors positively affecting both revenue and profit: Cost of hiring machines and technology; Expenses for improving machines and technology; Cost for testing new services/products; Training cost; New management method. Specifically, the greater the cost of hiring/buying specialized machines, equipment, software and new technologies in 2018, the greater the revenue and profit. The results for the cost of improvements to machines, equipment, specialized software, technology in 2018, costs for testing new products/services and training costs in 2018 are similar. These results appear to be new contributions for firm performance studies.

Normally, we assume that cost will decrease revenue and profit. However, the results in this case show that the following costs will help revenue and profit increase: expenses for hiring/buying machinery and equipment, specialized software, new technology; cost of improvements to machines, equipment, specialized software, technology; costs for testing new products/services; costs for training labors/human resources in hiring/innovating/technology research activities in 2018.

In [27], the author presented these costs to be called prevention costs or quality costs in the company. These costs are not only to ensure the creation of a product/service that meets market needs, but also to prevent customers from being dissatisfied with the product/service, thereby reducing the failure costs of the company. Therefore, these costs bring many benefits such as increasing customer satisfaction, increasing sales and profits.

In addition, the observed variable "new management method" has a positive impact on revenue and profit of businesses with a significant level of $p=1 \%$. In an organization, management greatly affects the performance of the company. With the business environment constantly changing, it is required that the management method must be improved and refreshed to suit the general context. That is the reason why implementing a new management and organization method in businesses positively affects revenue and profit.

Factors that only affect revenue: Using internet/computer networks; Private information website; Government's support; Investment in new technologies; New marketing method. Specifically, the revenue of businesses will be higher if businesses use internet or computer network, has private information website, get support from the government, invest in new technology or innovate the existing technology. The results are same as the results of some previous studies. However, if the enterprises apply new marketing methods, new experiences for customers, the revenue will decrease. The use of supporting tools such as computers, internet, websites will help businesses operate more effectively, leading to better sales. Businesses that have support in innovation will also have a better competitive advantage, hence, the revenue is also better. However, according to the analysis results, the revenue of the businesses that have new marketing methods and new experiences for customer's decreases; This may be due to the high cost of these marketing methods or the inappropriate marketing methods, resulting in low efficiency.

Factors that only affect profit: Quantity of new product types; Level of computer equipment; R\&D; Science and Technology Development Fund. The study results show that the more the new types of services/products are launched to the market in 2018, the higher profit the businesses get. Furthermore, the higher level of 
computer equipment, the greater the profit. Also, if the businesses have R\&D department or have Science and Technology Development Fund, the profit will increase. The results are equivalent to the results of some previous studies.

\section{Conclusions and policy implications}

The analysis results show that the factors of technology innovation, product innovation and organizational innovation all have observable variables affecting the revenue and profit of enterprises in four key industries in Ho Chi Minh City. The authors propose a few recommendations to improve business performance for these businesses as follows:

First, businesses should invest in prevention costs such as: innovation costs, costs of testing new products/services; training costs. These costs are essential for the sustainable development of businesses, improving operational efficiency as well as business performance[27].

Second, enterprises need to improve and innovate management methods in the organization to suit the business environment. The research results show that the "new management method" has the greatest positive impact on both revenue and profit. This reaffirms the role of management in the organization. Nowadays, there are many management methods in the world that Vietnamese enterprises can apply such as: ISO 9001, ISO 14001, ISO 22000, ISO 27000, etc. Businesses choose for themselves the most appropriate management model depending on the different industries and fields of operations. And it is greatly important to constantly improve and innovate to keep up with the changes in the business environment and organizational context.

Third, businesses should equip themselves with supporting tools such as computers, internet, private websites, etc. With the development of information technology nowadays, the above tools do not only help businesses increase revenue (according to analysis results), but also help businesses improve working efficiency, enhance brands, reach customers more easily, thereby improving the competitive advantage of businesses.

Fourth, the government needs to promote the support of innovation for businesses. The support here is not only financial but also support for skills training, management method updates to raise awareness as well as skills for workers; create a transparent startup ecosystem, a fair playing field for businesses. Finally, enterprises should have a research and development department or set up a science and technology (S\&T) development fund. According to the analysis results in 4 key industries in Ho Chi Minh City, enterprises that have either of these two sections will have higher profits. As experts have said, the philosophy in any management system is "do it right from the beginning". R\&D departments or S\&T development funds are the original incubators for ideas. If this nursery produces good seeds, of course the results will be good.

Limitation of the study: Although the paper has achieved some results, the research still has some limitations. The study only analyzes data in a specific period of time, has not yet analyzed data to see the fluctuation of the dependent variable over time. The thesis has just verified the results by logit regression model but has not compared the results with other models. The study was conducted only in Ho Chi Minh City but not in other localities in Vietnam. The authors hope to carry out further studies to improve the above limitations.

www.astesj.com

\section{References}

[1] National Department of Science and Technology Information, "Report "Global innovation policy"," 2012. [Online]. Available: http://www.vista.gov.vn/.

[2] S. Maranville, "Entrepreneurship in the Business Curriculum," J. Educ. Bus., 68(1), 27-31, Oct. 1992

[3] P. Frankelius, "Questioning two myths in innovation literature," J. High Technol. Manag. Res., 20(1), 40-51, 2009. https://doi.org/10.1016/j.hitech.2009.02.002

[4] K. Bhasin, "This Is The Difference Between 'Invention' And 'Innovation," 2012. [Online]. Available: https://www.businessinsider.com/this-is-thedifference-between-invention-and-innovation-2012-4.

[5] OECD, "Measuring Innovation: A New Perspective," 2010. [Online]. Available: http://www.oecd.org/.

[6] D. I. Prajogo and A. S. Sohal, "The integration of TQM and technology/R\&amp;D management in determining quality and innovation performance," Omega, 34(3), 296-312, Jun. 2006.

[7] E. OECD, Presentación Oslo Manual 2018(October. 2018.

[8] V. Souitaris, "Technological trajectories as moderators of firm-level determinants of innovation," Res. Policy, 31(6), 877-898, Aug. 2002. https://doi.org/10.1016/S0048-7333(01)00154-8

[9] M. Shafiq et al., "Towards successful global software development." In Proceedings of the Evaluation and Assessment in Software Engineering, 445-450. 2020. DOI: https://doi.org/10.1145/3383219.3383283

[10] P. Kemp, R., Pearson, "Final Report MEI Project about Measuring Ecoinnovation: Deliverable 15 of MEI Project," 2008.

[11] Ho Chi Minh City General Statistics Office, "Statistical Yearbook," 2018. [Online]. Available: http://www.pso.hochiminhcity.gov.vn/.

[12] P. Koellinger, "The relationship between technology, innovation, and firm performance-Empirical evidence from e-business in Europe," Research Policy, 37(8), $\quad 1317-1328, \quad 2008$. https://doi.org/10.1016/j.respol.2008.04.024

[13] J. Carlos Pinho, "TQM and performance in small medium enterprises," Int. J. Qual. Reliab. Manag., 25(3), 256-275, Mar. 2008 https://doi.org/10.1108/02656710810854278

[14] M. Terziovski, "Innovation practice and its performance implications in small and medium enterprises (SMEs) in the manufacturing sector: a resource-based view," Strateg. Manag. J., p. n/a-n/a, 2010.

[15] C. C. J. Cheng, C. Yang, and C. Sheu, "The link between eco-innovation and business performance: a Taiwanese industry context," J. Clean. Prod., 64, 81-90, Feb. 2014.

[16] K. Rangus and A. Slavec, "The interplay of decentralization, employee involvement and absorptive capacity on firms' innovation and business performance," Technol. Forecast. Soc. Change, 120, 195-203, 2017.

[17] M. Madaleno, M. Robaina, M. Ferreira Dias, and M. Meireles, "Dimension effects in the relationship between eco-innovation and firm performance: A European comparison," Energy Reports, 6, 631-637, Feb. 2020.

[18] B. A. Asunka, Z. Ma, M. Li, and O. A. Anaba, "Linking Innovation to Firm Performance in Developing Countries: the Role of Trade Liberalization," Eur. J. Bus. Manag. Res., 5(3), 2020.

[19] N. Thao, "Ho Chi Minh City focuses on developing 4 key industries," 2017. [Online]. Available: http://www.ipcs.vn/vn/tp-ho-chi-minh-tap-trung-phattrien-4-nganh-cong-nghiep-trong-yeu-W1422.htm.

[20] A. N. Nguyen, N. Q. Pham, C. D. Nguyen, and N. D. Nguyen, "Innovation and exports in Vietnam's SME sector,” Eur. J. Dev. Res., 20(2), 262-280, Jun. 2008.

[21] Q. N. Nguyen and V. N. Mai, "Factors affecting business performance of small and medium-sized enterprises in Can Tho City," Sci. J. Can Tho Univ.19b, 122-129, 2011.

[22] Q. M. Nhưt, "The effects of science and technology investment on business performance of agricultural enterprises in Ben Tre province," Can Tho Univ. J. Sci., 54(1), p. 187, 2018.

[23] E. Calza, M. Goedhuys, and N. Trifković, "Drivers of productivity in Vietnamese SMEs: the role of management standards and innovation," Economics of Innovation and New Technology, 28(1), 23-44, 2019.

[24] M. L. Yeh, H. P. Chu, P. J. Sher, and Y. C. Chiu, "R\&D intensity, firm performance and the identification of the threshold: Fresh evidence from the panel threshold regression model," Appl. Econ., 42(3), 389-401, 2010.

[25] N. Kraiczy and N. Kraiczy, Innovation and firm performance, July. 2013.

[26] Vu, Nguyen, Ho, and Vuong, "Determinants of Vietnamese Listed Firm Performance: Competition, Wage, CEO, Firm Size, Age, and International Trade," J. Risk Financ. Manag., 12(2), 62, Apr. 2019.

[27] J. S. Oakland, Total quality management and operational excellence: Text with cases. 2014 